\title{
Е.Т. Свешникова
}

\section{СРАВНИТЕЛЬНЫЙ АНАЛИЗ ВЗГЛЯДОВ НА МЕСТО И КЛАССИФИКАЦИЮ ВАЛЮТНЫХ РИСКОВ}

\begin{abstract}
Статья посвящена исследованию сущности категории «валютный риск», уточнению его места в классификации банковских рисков и выявлению механизмов влияния на деятельность коммерческих банков. На основе анализа различных подходов предложена многокритериальная система классификации валютных рисков. Приведены авторские предложения относительно проблематики описанных вопросов, в частности, обоснована необходимость объединения фондового, прочентного и валютного рисков в группу рыночных, а также закрепления единого нормативно-правового определения валютного риска в законодательстве.

Ключевые слова: рыночный риск, валютный риск, коммерческий банк, банк, классификация, Базельские соглашения, Базель I, Базель II, Базель III.
\end{abstract}

Экономическая сущность валютного риска банка заключается в том, что он является следствием несбалансированности активов и пассивов по каждой из валют по срокам и суммам и связан с интернационализацией рынка банковских операций, функционированием транснациональных банков и компаний, миграцией капитала между странами и ростом объемов спекулятивных валютных операций.

Актуальность выбранной темы заключается во все возрастающих масштабах спекулятивности операций на валютных рынках. Так, из ежедневного объема валютных сделок по состоянию на апрель 2010 г., который достиг отметки 4,0 трлн долл. США [1], только 10\% действительно опосредствуют движение реальных товаров и капиталов. Годовой объем международных финансовых операций в 10-15 раз превышает масштабы мировой торговли. Рост фиктивного капитала и спекулятивные действия в этой сфере существенно усложняют соблюдение равновесия между важнейшими сферами мирового хозяйства.

Вопросы в сфере определения природы валютного риска освещены в исследованиях зарубежных: М. Адлера (М. Adler), А. Гассема (A. Ghassem) [2], Д. Мерфи (D. Murphy) [3], М. Папайоану (M. Рараioannou) [4], К. Рэдхэда (K. Redhead) [5], А. Шапиро (А. Shapiro) [6], А. Стоунхилла (A. Stonehill) и др., а также российских и украинских ученых и практиков: О.И. Бутук [7], В.В. Витлинского [8], А.С. Гальчинского [9], О.А. Криклий [10], Л.А. Примостки, И.В. Сало и др. В их публикациях освещены разносторонние взгляды на типологию и место валютных рисков, но при всей значимости разработок перечисленных авторов из-за сложности и многоаспектности категории «валютный риск» сегодня отсутствует единый подход к этой проблематике.

В связи с этим целью данной статьи является уточнение категории валютного риска и его классификация. 
По классификации Базельского комитета валютный риск вместе с фондовым и процентным относят к группе рыночных рисков. Данные подходы согласно Консультативному документу (1996 г. с ред. 2003 г. и 2005 г.) Basel I [11] впервые были реализованы в банковском законодательстве РФ в Положении [12], впоследствии согласно требованиям Basel II [13, 14] учтены в нормативных документах ЦБ РФ [15, 16], а требования Basel II.5 [17] - в Положении [18]. Постановление НБУ [19], напротив, отделяет и рыночный, и валютный риски; согласно ему рыночный риск - это имеющийся или потенциальный риск для поступлений и капитала, который возникает из-за неблагоприятных колебаний стоимости ценных бумаг и товаров и курсов иностранных валют по тем инструментам, которые есть в торговом портфеле.

Кроме того, среди экономистов также нет согласованной точки зрения относительно групповой принадлежности валютного риска: одни относят его к финансовым [20. С. 101-102], другие - к рыночным [21; 22. С. 207; 23. С. 106-107; 24. С. 261-262; 25], третьи - к обеим [10. С. 140]. А исходя из классификации категорий финансового менеджмента валютный риск относят в группу финансовых ценовых рисков.

Сравнение подходов различных ученых касательно места валютного в обобщенной классификации рисков позволяет автору предложить приведенную схему на рис. 1, а также представить свое видение этого вопроса, согласно которому результатом реализации финансовых рисков являются финансовые убытки потери стоимости финансовых активов или появления дополнительных расходов, нефинансовых - нефинансовые убытки. Рыночный риск, по мнению автора, - это риск возникновения убытков или недополучения прибыли в результате неожиданных изменений рыночных параметров - валютных курсов и цен на банковские металлы (валютный риск), процентных ставок (процентный риск), цен на финансовые активы (фондовый риск), на товарные активы (товарный риск).

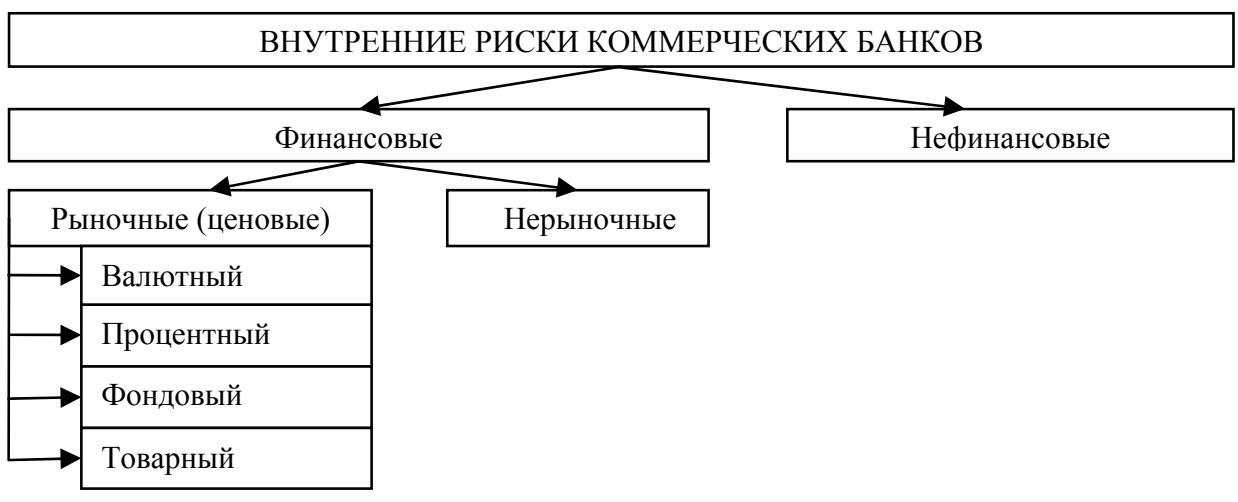

Рис. 1. Место валютного риска в системе рисков коммерческих банков

Также в украинской банковской практике целесообразно объединение фондового, процентного и валютного рисков в группу рыночных, что связано с дальнейшим развитием национальной финансовой системы, ее интернацио- 
нализацией и концентрацией. Отделение этих рисков в будущем может, на наш взгляд, вызвать проблемы в банковской системе Украины по управлению ими.

В зарубежной научной литературе приведены следующие подходы к определению категории валютного риска. Д. Мерфи [3] утверждает, что валютный риск - это позиция, которая деноминирована в валюте, не являющейся валютой учета держателя данной позиции, а П.С. Роуз [26. С. 146], что это вероятность того, что изменение курсов иностранных валют (доллара, фунта стерлингов, франка, иены и т.д.) приведет к появлению у банка убытков вследствие изменения рыночной стоимости его активов и пассивов. Д. Айтман рассматривает валютный риск как потенциал изменений в доходности, чистых денежных потоках и рыночной стоимости фирмы в результате изменений обменных курсов [27], М. Папайоану - как вызванные движением обменного курса потенциальные прямые (в результате нехеджированной позиции) или косвенные потери в финансовых потоках фирмы, ее активах и пассивах, чистой прибыли и, в свою очередь, ее рыночной стоимости [4]. Х. ван Грюнинг [22. С. 207] указывает на то, что валютный риск может быть формой рыночного риска с дополнительным элементом риска ликвидности, рассматривая валютный риск не как самостоятельное явление, а как комплекс рисков.

В настоящее время происходит реформирование банковского надзора на рискоориентированной основе. Для осуществления банковского надзора НБУ выделил девять категорий риска (рис. 2), которые не являются взаимоисключающими, любой продукт или услуга могут подвергать банки нескольким рискам одновременно, однако для удобства анализа НБУ выявляет и оценивает эти риски отдельно [19].

\begin{tabular}{|c|c|c|}
\hline \multirow{9}{*}{ 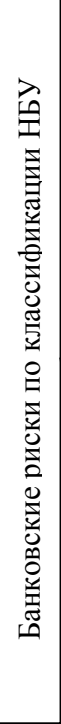 } & \multirow{6}{*}{ 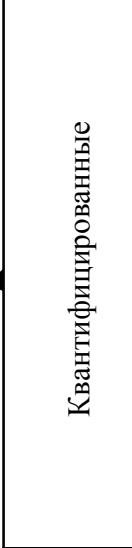 } & $\begin{array}{l}\text { Кредитный риск с разновидностями: индивидуальный кредитный } \\
\text { риск, портфельный кредитный риск, риск страны с компонентом, } \\
\text { известным как трансферный риск }\end{array}$ \\
\hline & & Риск ликвидности с его разновидностью - риском ликвидности рынка \\
\hline & & $\begin{array}{l}\text { Риск изменения процентной ставки с разновидностями: риск измене- } \\
\text { ния стоимости ресурсов, риск изменения кривой доходности, базо- } \\
\text { вый риск, риск права выбора }\end{array}$ \\
\hline & & Рыночный риск \\
\hline & & $\begin{array}{l}\text { Валютный риск с разновидностями: риск сделки, риск пересчета из } \\
\text { одной валюты в другую (трансляционный риск), экономический ва- } \\
\text { лютный риск }\end{array}$ \\
\hline & & Операционно-технологический риск \\
\hline & \multirow{3}{*}{ 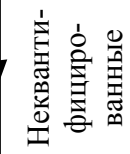 } & Риск репутации \\
\hline & & Юридический риск \\
\hline & & Стратегический риск \\
\hline
\end{tabular}

Рис. 2. Классификация банковских рисков согласно методике НБУ [19] 
Важное место в деятельности коммерческих банков занимают именно валютные риски, которые в условиях депрессивного состояния мировой и национальных экономик особенно обострились и привели к значительным негативным последствиям банковской системы Украины. При этом неквантифицированные риски (стратегический, юридический и риск репутации) трудно точно измерить количественно, поэтому НБУ [19] было решено, что по ним будут оцениваться только совокупный риск и его направление.

На сегодняшний день в украинской практике единого определения валютного риска не существует.

В соответствии с постановлениями Правления НБУ $[19,28]$ валютный риск - это имеющийся или потенциальный риск для поступлений и капитала, который возникает из-за неблагоприятных колебаний курсов иностранных валют и цен на банковские металлы. То есть риск изменения стоимости банковских металлов уже определяется как составляющая валютного риска, поскольку банковские металлы давно используются как товар на валютном рынке, в частности, рынка FOREX. П(С)БУ 13 «Финансовые инструменты» [29] раскрывает сущность валютного риска с бухгалтерской точки зрения как вероятность того, что стоимость финансового инструмента будет изменяться в результате изменений валютного курса.

Украинские авторы В.А. Ющенко, В.И. Мищенко [21. С. 19] с позиции субъектов рассматривают валютный риск как возможность денежных потерь субъектов валютного рынка из-за колебаний валютных курсов. Аналогичного мнения придерживается В.В. Витлинский, давая следующее толкование: «угроза понести убытки, связанные с изменением (колебанием) курсов иностранных валют в ходе осуществления сделок купли-продажи» [8. С. 16]. Другие авторы утверждают, что валютный риск - это возможность потерь от изменения стоимости иностранной валюты относительно национальной [30. С. 183], возможность несоответствия валютного курса значениям, ожидаемым лицами, принимающими решения под действием рыночных факторов [31], размер альтернативных затрат для выбранной стратегии управления валютным риском, а на конечном этапе управления - это мера качественной и количественной оценки непредвиденных изменений валютного курса [32. С. 73].

Подобные трактования категории валютного риска не отражают всей его специфики, поскольку он может отклоняться в разные стороны от ожидаемого значения, т.е. иметь как непредвиденные убытки, так и прибыли. Например, О.Е. Коцин отмечает, что валютный риск связан с возможностью получения как ущерба, так и прибыли в результате колебания курса валют и в неблагоприятную сторону, и в благоприятную [33]. А М.А. Ребрик после проведения наукоемкого исследования экономических категорий «риск» и «валютный риск» предложил авторские определения, выделив основные направления валютного риска как вероятности потерь, как неопределенности последствий действий, как события, как экспозиции, удержание позиций, как следствие действий, и на этой базе удачно дал свое толкование этой категории: «комбинация источника риска (которым являются краткосрочные и долгосрочные колебания валютных курсов), валютной экспозиции (которая характеризует степень склонности к потерям или доходы) и последствий (кото- 
рые, в конечном итоге, выражаются в масштабах потерь или дополнительных выгод для банка)» [34. С. 139-140]. Но валютный риск не является сугубо банковским риском, ему подвержены все владельцы как иностранных, так и национальных валют (государство, организации, частные лица).

По мнению автора, наиболее полным является законодательное определение валютного риска, поскольку он рассматривается с точки зрения возможных потерь по имеющимся ресурсам и ресурсам, поступление которых ожидается в будущем, а также учитывает колебания цен на банковские металлы, но следует утвердить его единое трактование во всех нормативных документах.

Н.М. Ткачук в полной мере соглашается с позицией В.А. Ющенко и В.И. Мищенко [31] в том, что главной причиной валютного риска являются кратко- и долгосрочные колебания обменных курсов, которые зависят от спроса и предложения валюты на национальном и международном валютных рынках [23. С. 107], но эта точка зрения отражает только влияние рынка на величину валютной позиции без учета действий банка по ее изменению в соответствии с удовлетворением потребностей в валюте как конкретно банка, так и своих клиентов, а также по уравновешиванию несбалансированности по срокам и объемам активов и пассивов банка в каждой из иностранных валют или банковских металлов согласно балансу банка. При этом степень склонности к валютному риску определяется открытой валютной позицией по разным иностранным валютам и банковским металлам, т.е. степенью неуравновешенности балансовых и внебалансовых статей, динамикой валютных курсов, квалификацией и корректностью действий лиц, непосредственно выполняющих валютные операции.

Кроме того, стоит проблема отсутствия единой четкой классификации валютных рисков в экономической научной литературе. На наш взгляд, причина этого заключается в сложности разработки универсальных классификационных признаков из-за следующего: наличия многообразия валютных рисков, с которыми постоянно сталкиваются банки в своей деятельности; невозможности проведения четких границ между ними из-за их тесных связей друг с другом; стремительности развития финансового сектора, порождающей новые виды и типы валютных рисков; отличия в динамичности и интенсивности воздействия валютных рисков.

Стандартизированный подход Basel II.5 к оценке рыночного риска, использующий довольно громоздкий математический аппарат, в связи с чем рекомендуемый небольшим банкам, выделяет около 20 категорий по 5 его типам в каждой, согласно типу риска по инструменту (процентный, валютный, товарный, кредитный и фондовый). Касательно валютного выделяют три срока поступления по денежным потокам в иностранной валюте (менее одного года, от одного до трех лет и в течение трех лет). Подход, основанный на внутренней модели банка, предусматривает деление финансовых инструментов внутри торгового портфеля по типу инструмента, рынку, на котором торгуется, или фактору риска, существенному для него. Кроме того, Базельский комитет определяет только трансляционную и транзакционную формы валютного риска и, в отличие от НБУ, считает нецелесообразным выделять экономический риск. B Basel III [35] уже предложены два подхода к делению 
активов на торговый и банковский портфели: 1) на основе спроса на финансовый инструмент и величины его риска; 2) на основе расчетной величины регулятивного капитала, необходимого для покрытия рыночного риска по финансовому инструменту, т.е. исходя из их деления на оцениваемые по справедливой и амортизированной стоимости.

В то же время среди экономистов еще больше разногласий относительно разновидности валютных рисков. Так, А.А. Волицкая по критерию возникновения разделяет валютные риски коммерческого банка на две основные группы: активные (операционный, прямой экономический (инвестиционный), фьючерсный, риск конвертации (включая курсовой и инфляционный риски), риск страны) и пассивные (риск служащих, организационный, балансовый, технологический, трансляционный, конкурентный, риск открытой валютной позиции) [36. С. 80-81]. М.А. Ребрик выделяет прямой валютный риск, к которому относит транзакционный, трансляционный и стратегический его подвиды, и косвенный [37. С. 312-313]. Для транзакционного и трансляционного значение эластичности стоимости валютной позиции всегда равно единице, а для других может быть как больше, так и меньше. Все же большинство точек зрения сходится на классификации [8. С. 442; 21. С. 22; 24. С. 261-262; 33. С. 82-84], приведенной в табл. 1.

Таблица 1. Виды и характеристика валютных рисков в зависимости от характера, места и времени их возникновения

\begin{tabular}{|c|c|}
\hline $\begin{array}{c}\text { Разновидность валютного } \\
\text { риска }\end{array}$ & Характеристика риска \\
\hline 1 & 2 \\
\hline $\begin{array}{l}\text { Транзакционный }[2,38, \\
39] \\
\text { Другие варианты назва- } \\
\text { ния: } \\
\text { - операционный [5. С. } \\
\text { 33]; } \\
\text { - валютно-операционный } \\
\text { (контрактный) [7], } \\
\text { - риск валютных опера- } \\
\text { ций; } \\
\text { - риск, связанный с ва- } \\
\text { лютными сделками, } \\
\text { - риск сделок; } \\
\text { - риск трансакции / тран- } \\
\text { закции [19, 28]; } \\
\text { - конверсионный [33]) }\end{array}$ & $\begin{array}{l}\text { Влияние непредвиденных изменений в валютных курсах на денежные } \\
\text { потоки от всех контрактов, заключенных до момента изменений в } \\
\text { валютных курсах, но со сроком исполнения после указанных измене- } \\
\text { ний [2] } \\
\text { Возможность получения валютных доходов или убытков компании в } \\
\text { связи с выполнением валютно-деноминированных контрактов [7] } \\
\text { Связан с торговыми операциями, а также с денежными сделками по } \\
\text { финансовому инвестированию и дивидендных платежей или получе- } \\
\text { ния средств в иностранной валюте в будущем, заключается в том, что } \\
\text { неблагоприятные колебания курсов иностранных валют влияют на } \\
\text { реальную стоимость открытых валютных позиций. Однако поскольку } \\
\text { он, как правило, следует из операций маркетмейкерства, дилинга и } \\
\text { принятия позиций в иностранных валютах, этот риск рассматривается } \\
\text { в рекомендациях по рыночному риску [19] } \\
\text { Заключается в том, что неблагоприятные колебания курсов иностран- } \\
\text { ных валют влияют на реальную стоимость открытых валютных пози- } \\
\text { ций [28] } \\
\text { Риск потенциальных убытков по конкретным операциям, связанный с } \\
\text { нестабильностью стоимости иностранной валюты и денежных пото- } \\
\text { ков, измеряемых в валютах, будущая стоимость которых не опреде- } \\
\text { лена [33. С. 82-83] } \\
\text { Имеет денежно-поточный характер, т.е. касается изменений в реаль- } \\
\text { ных, а не бухгалтерских денежных потоках [38. С. 57] } \\
\text { Эффект от изменения валютных курсов на текущие активы и пассивы, } \\
\text { деноминированные в иностранной валюте [39] }\end{array}$ \\
\hline
\end{tabular}


Продолжение табл. 1

\begin{tabular}{l}
\hline \multicolumn{1}{c}{1} \\
\hline Экономический валют- \\
ный $[19,21,28,33]$ \\
Другие варианты назва- \\
ния: \\
- конкурентно-валютный \\
[9]); \\
- стратегический валют- \\
ный [38]
\end{tabular}

$\frac{2}{\text { Негативные долгосрочные изменения в общих рыночных позициях }}$ но-курсовых трендах [7]

Связан с возможностью потери доходов по будущим контрактам из-за изменения общего экономического состояния страны и конкурентоспособности банковского учреждения или его структур на внешнем рынке по причине существенного изменения обменных курсов [19, 21]

Заключается в изменениях конкурентоспособности финансового учреждения или его структур на внешнем рынке по причине существенного изменения обменных курсов [28]

Чаще всего определяется как вероятность неблагоприятного воздействия изменений валютного курса на экономическое положение компании [33. С. 83-84]

Эффект от изменения валютных курсов на доход и операционные расходы [39]

Бухгалтерский $[6,21,33$, 38]

Влияние непредвиденных изменений в валютных курсах на балансовую стоимость филиалов, которое транслируется для консолидации в валюту страны базирования материнской компании [2]

Другие варианты назва- Изменения в бухгалтерской стоимости акционерного капитала в рения:

- трансляционный [2, 5, 19, 21, 28, 33, 39];

- балансовый [5];

-валютно-учетный (учетно-трансляционный) [7];

- конверсионный [9];

- риск переоценки;

- риск перевода;

- риск пересчета из одной валюты в другую [19]; - расчетный балансовый [33] зультате трансляции финансовой отчетности, выраженной в иностранной валюте, в консолидированную отчетность, в которой используется единая валюта [6]

Негативные изменения в нетто-стоимости фирмы при конверсии из инвалют в национальную валюту финансовой отчетности по ее внешнеэкономическим операциям вследствие модификации курсов [7] Связан с переоценкой активов и пассивов и прибыли зарубежных филиалов в национальную валюту, а также может возникать при экспорте или импорте инвестиций [21]

Заключается в том, что величина эквивалента валютной позиции в отчетности изменяется в результате изменений обменных курсов, используемых для перечисления остатков в иностранных валютах в базовую (национальную) валюту [28]

Заключается в том, что величина эквивалента валютной позиции в отчетности изменяется в результате изменений обменных курсов, используемых для пересчета остатков в иностранной валюте в базовую (национальную) валюту; также может возникать во время экспорта или импорта инвестиций; учитывают при составлении финансовой и бухгалтерской отчетности, на показатели которого и влияет; относится к изменениям бухгалтерских ценностей прибыли и собственного капитала компании, которые произошли из-за колебания валютного курса [33. С. 83]

Связан с влиянием изменения валютных курсов на бухгалтерскую прибыль и собственный капитал банка и имеет ретроспективный характер относительно момента изменения валютных курсов [38. C. 57-60]

Эффект от изменения валютных курсов на трансляцию иностранных филиалов [39] 28].

Данная классификация также приводится в нормативных документах [19,

Следует отметить, что кроме указанных выше ученые $[38,40]$ выделяют также стратегический, конъюнктурный, кредитный, налоговый валютные риски.

Среди ученых, чьи труды были проанализированы, утвердился системный подход к выделению и анализу валютных рисков, но до сих пор не суще- 
ствует единого мнения относительно названий его видов. С целью предотвращения дальнейшего раздвоения мнений в понятийном аппарате базовой классификации валютного риска следует утвердить следующие его виды:

прямой как вероятность потерь банка в результате переоценки его открытых позиций и уменьшения прибыли по будущим операциям вследствие снижения валютного курса и цен на банковские металлы, к нему следует отнести транзакционный, бухгалтерский, экономический валютные риски. При этом к экономическому валютному риску целесообразно отнести все виды валютных рисков, связанных с влиянием волатильности валютных курсов на реальные денежные потоки, а следовательно, и на экономическую стоимость банка. Напротив, бухгалтерский касается изменений в балансовой стоимости банка, непосредственно воздействуя только на бухгалтерские денежные потоки;

$>$ опосредованный (непрямой):

с позиции страны - это вероятность потерь определенной части конкурентоспособности национальных производителей по сравнению с иностранными;

с позиции банка - это возможность его потери в случае снижения кредитоспособности заемщиков из-за неблагоприятного изменения валютного курса, для чего необходим анализ каждого заемщика и его зависимости от курсовой волатильности.

Валютные риски как составляющую совокупных банковских рисков классифицируют и по другим признакам. Обобщив различные подходы, считаем целесообразным предложить следующую классификацию по набору основных признаков (табл. 2).

Таблицุа 2. Классификация валютных рисков

\begin{tabular}{l|l}
\hline \multicolumn{1}{c|}{ Признак классификации } & \multicolumn{1}{c}{ Вид валютного риска } \\
\hline \multicolumn{1}{c|}{ По возможности страхования } & Риск, который страхуется \\
& Риск, который не страхуется \\
\hline По источнику возникновения & $\begin{array}{l}\text { Внешний риск } \\
\text { Внутренний риск }\end{array}$ \\
\hline По объекту & Риск отдельных банковских продуктов \\
& Риск торгового портфеля банка \\
& Риск деятельности банка в целом \\
\hline По рисковой позиции & Риск по единичным валютным позициям \\
& Риск валютного портфеля \\
\hline По уровню принятия решений & Макроэкономический риск \\
& Риск на равные банковские учреждения \\
& Риск на равные подразделения банка \\
& Риск ответственного лица \\
\hline По характеру учета & Балансовый риск \\
& Внебалансовый риск \\
\hline По уровню прогнозируемости & Прогнозируемый риск \\
& Непрогнозируемый риск \\
\hline По сфере возникновения & Риск относительно клиента \\
& Риск относительно гаранта (поручителя) \\
& Риск относительно страховщика \\
& Риск относительно другого банка \\
& Риск банковского продукта \\
& Риск изменения внешней среды \\
\hline
\end{tabular}


Продолжение табл. 2

\begin{tabular}{|c|c|}
\hline 1 & 2 \\
\hline По причинам возникновения & $\begin{array}{l}\text { Законодательный риск } \\
\text { Объективный риск } \\
\text { Субъективный риск }\end{array}$ \\
\hline По размерам потерь & $\begin{array}{l}\text { Приемлемый риск } \\
\text { Допустимый риск - потери возможны, но их размер меньше } \\
\text { ожидаемой прибыли } \\
\text { Критический риск первой степени связан с угрозой получения } \\
\text { нулевого дохода, риск второй степени связан с возможностью } \\
\text { потерь в размере полных издержек } \\
\text { Катастрофический риск }\end{array}$ \\
\hline $\begin{array}{l}\text { По характеру проявления во } \\
\text { времени }\end{array}$ & $\begin{array}{l}\text { Постоянный риск присущ всему периоду валютной операции и } \\
\text { связан с действием постоянных факторов } \\
\text { Временный риск возникает на отдельных стадиях валютной опе- } \\
\text { рации }\end{array}$ \\
\hline $\begin{array}{l}\text { По уровню осуществления } \\
\text { анализа }\end{array}$ & $\begin{array}{l}\text { Индивидуальный риск } \\
\text { Общий риск }\end{array}$ \\
\hline По методам минимизации & $\begin{array}{l}\text { Избежание риска } \\
\text { Снижение уровня риска } \\
\text { Передача (страхование) риска }\end{array}$ \\
\hline По способу влияния на риск & $\begin{array}{l}\text { Риск, что регулируется банком самостоятельно } \\
\text { Риск, что передается страховщику, гаранту, поручителю } \\
\text { Риск, который распределяется между различными банками } \\
\end{array}$ \\
\hline $\begin{array}{l}\text { По целесообразности осуще- } \\
\text { ствления валютных операций }\end{array}$ & $\begin{array}{l}\text { Оправданный риск } \\
\text { Неоправданный риск }\end{array}$ \\
\hline По вероятности реализации & $\begin{array}{l}\text { Реализованный риск } \\
\text { Потенциальный риск }\end{array}$ \\
\hline По финансовым последствиям & $\begin{array}{l}\text { Риск, вследствие которого есть финансовые потери } \\
\text { Риск, вследствие которого есть потерянная выгода } \\
\text { Риск, вследствие которого есть финансовый доход }\end{array}$ \\
\hline $\begin{array}{l}\text { По эффектам от изменения } \\
\text { валютного курса }\end{array}$ & $\begin{array}{l}\text { Риск, приводящий к изменению чистой прибыли банка } \\
\text { Риск, приводящий к изменению рыночной стоимости капитала } \\
\text { банка }\end{array}$ \\
\hline $\begin{array}{l}\text { По сроку действия валютной } \\
\text { сделки }\end{array}$ & $\begin{array}{l}\text { Риск по краткосрочным сделкам } \\
\text { Риск по среднесрочным сделкам } \\
\text { Риск по долгосрочным сделкам }\end{array}$ \\
\hline $\begin{array}{l}\text { По возможности устранения } \\
\text { (по возможности диверсифи- } \\
\text { кации) }\end{array}$ & $\begin{array}{l}\text { Систематический (недиверсифицированный, рыночный) риск } \\
\text { возникает при изменении отдельных стадий экономического } \\
\text { развития страны, изменения конъюнктуры финансового рынка } \\
\text { Несистематический (диверсифицированный, специфический) } \\
\text { риск присущ отдельным направлениям финансовой деятельности } \\
\text { и характеру финансовых операций }\end{array}$ \\
\hline
\end{tabular}

Предложенная комплексная классификация валютного риска позволяет всесторонне рассмотреть этот вид риска и разработать действенные меры по его оптимизации и (или) минимизации.

Таким образом, анализ дефиниции «валютный риск» среди экономистов показал разноплановость точек зрения на рассматриваемую проблему, при этом стоит в стороне, но по содержательному смыслу выгодно отличается законодательное определение, которое является полным и актуальным. В общем плане система оценки рисков НБУ [19], разработанная согласно международному опыту, кратко, но по сути дает рекомендации относительно видов рисков, сложившихся на Украине. При этом автором рекомендовано в украинском законодательстве объединить фондовый, процентный и валютный риски в группу рыночных, так как отделение этих рисков в будущем 
может, на взгляд автора, вызвать проблемы в банковской системе Украины относительно управления ими.

\section{Лumepamypa}

1. Отчеты Банка международных расчетов за 1996-2013 гг. [Электронный ресурс]. URL: http://www.bis.org/triennial.htm (дата обращения: 30.03.2015).

2. Ghassem A.H. Managing Global Financial and Foreign Exchange Rate Risk. Hoboken, New Jersey : John Wiley \& Sons, Inc., 2003. 400 p.

3. Murphy D. Understanding Risk. The Theory and Practice of Financial Risk Management. Taylor and Francis, 2008. 472 p.

4. Papaioannou M.G. Exchange Rate Risk Measurement and Management: Issues and Approaches for Firms // IMF Working Paper. 2006. Vol. 255.

5. Redhead K., Hughes S. Financial Risk Management. Cambridge: Gower Pub Co, 1988. 257 p.

6. Shapiro Alan C. Multinational financial management. 8th edition. Published by John Wiley and Son, Inc., 2006. 768 p.

7. Бутук О.І. Валютно-фінансові відносини: навч. посіб. К.: Знання, 2006. 349 с.

8. Вітлінський В.В. Ризикологія в економіці та підприємництві: монографія. К.: КНЕУ, 2004. $480 \mathrm{c}$.

9. Гальчинський А.С. Теорія грошей: навч. Посібник. 4-те вид., змінене і допов. К.: Видавництво Соломії Павличко «Основи», 2001. 412 с.

10.Банківський менеджмент: питання теорії та практики: монографія / [О.А. Криклій, Н.Г. Маслак, О.М. Пожар та ін.]. Суми: ДВНЗ «УАБС НБУ», 2011. 152 с.

11.Amendment to the Capital Accord to incorporate market risks [Electronic resource] / Basel Committee on Banking Supervision. Basel, november 2005 [Электронный pecypc]. URL: http://www.bis.org/publ/bcbs119.pdf (дата обращения: 30.03.2015).

12.Положение о порядке расчета кредитными организациями размера рыночных рисков (утв. Банком России 24.09.1999 № 89-П) (ред. от 30.11.2004) (утратило силу с 01.01.2008 в связи с изданием Указания ЦБ РФ от 14.11.2007 №1910-У).

13.Abstract of «Basel II: International Convergence of Capital Measurement and Capital Standards: a Revised Framework», Basel Committee on Banking Supervision,, June 2004 (Международная конвергенция измерения капитала и стандартов капитала: новые подходы, Basel II) [Электронный pecypc]. URL: http://www.bis.org/publ/bcbs107.htm (дата обращения: 30.03.2015).

14. Core Principles for Effective Banking Supervision, Basel Committee on Banking Supervision, October 2006, updated as of 14.09.2012) (Основополагающие принципы эффективности банковского надзора, Basel II) [Электронный pecypc]. URL: http://www.bis.org/publ/bcbs129.htm (дата обращения: 30.03 .2015 ).

15. O типичных банковских рисках: Указание Центробанка России № 70-Т от 23.06.2004 // Вестн. Банка России от 30.06.2004. № 38 (762) [Электронный ресурc]. URL: http:// www.cbr.ru/ Publ/ Vestnik/Ves040630038.zip (дата обращения: 30.03.2015).

16.Положение о порядке расчета кредитными организациями величины рыночного риска (утв. Банком России 14.11.2007 № 313-П) (ред. от 28.04.2012) (Зарегистрировано в Минюсте России 06.12.2007 № 10638) (утратило силу с 01.02.2013 в связи с изданием Положения Банка России от 28.09.2012 №387-П, утвердившего новый порядок).

17. Revisions to Basel II market risk framework, Basel Committee on Banking Supervision, July 2009, updated as of 31.12.2010 (Пересмотр подходов Базеля II к оценке рыночного риска, Basel II.5) [Электронный pecypc]. URL: http://www.bis.org/publ/bcbs193.htm (дата обращения: 30.03.2015).

18. Положение о порядке расчета кредитными организациями величины рыночного риска (утв. Банком России 28.09.2012 № 387-П) (ред. от 25.11.2014) (Зарегистрировано в Минюсте России 09.11.2012 № 25783).

19. Методичні вказівки з інспектування банків «Система оцінки ризиків»: Постанова Правління НБУ від 15.03.2004 №104 [Электронный ресурс]. URL: http://zakon.rada.gov.ua/cgibin/laws/main.cgi?nreg=v0104500-04 (дата обращения: 30.03.2015).

20. Мішин О.Ю. Багатокритеріальна система класифікації ризиків [Текст] // Проблеми і перспективи розвитку банківської системи України: збірник наукових праць / Державний вищий 
навчальний заклад «Українська академія банківської справи Національного банку України». Суми, 2005. Т. 13. С. 98-103.

21.Ющеенко B.A., Міщенко B.I. Управління валютними ризиками [Текст]: Навчальний посібник. К.: Товариство «Знання», КОО, 1998. 444 с.

22. Грюнинг Хенни ван, Брайович Братанович С. Анализ банковских рисков. Система оценки корпоративного управления и управления финансовым риском: пер. с англ. М.: Весь мир, 2004. 304 c.

23.Ткачук Н.М., Стремецька Ю.І. Методи управління валютним ризиком банку // Наука й економіка. 2010. №2 (18). С. 106-112.

24. Сідолако М.С. Банківські ризики та управління ними // Проблеми і перспективи розвитку банківської системи України : зб. наук. праць // Державний вищий навчальний заклад «Українська академія банківської справи Національного банку України». Суми, 2007. Т. 20. С. 261265 .

25. Risk Management Guidelines for Derivatives: Basel Committee on Banking Supervision, July 1994 [Электронный ресурc]. URL: <http://www.bis.org/publ/bcbsc211.pdf (дата обращения: 30.03.2015).

26. Роуз Питер С. Банковский менеджмент: пер. с англ. с 3-го изд. М.: «Дело Лтд», 2008. $433 \mathrm{c}$.

27.Eiteman D.K., Stonehill Arthur I., Moffett Michael H. Multinational Business Finance. 9th edition. Published by Addison-Wesley Longman, Inc., 2001. 784 p.

28. Методичні рекомендації щодо організації та функціонування систем ризикменеджменту в банках України: Постанова Правління НБУ від 02.08.2004 № 361 [Электронный pecypc]. URL: http://zakon.rada.gov.ua/cgi-bin/laws/main.cgi?nreg=v0361500-04 (дата обращения: 30.03.2015).

29. Положення (стандарт) бухгалтерського обліку 13 «Фінансові інструменти»: Наказ Міністерства фінансів України від 30.11.2001 № 559, зареєстрований в Міністерстві юстиції України 19.12.2001 р. за № 1050/6241 (зі змінами від 09.12.2011 р.) [Электронный ресурс]. URL: http://zakon.rada.gov.ua/cgi-bin/laws/main.cgi?nreg=z1050-01 (дата обращения: 30.03.2015).

30.Шелудько В.М. Фінансовий ринок. К.: Знання, 2006. 535 с.

31. Лобанов А.А., Чугунова А.В. Энциклопедия финансового риск-менеджмента М.: Альпина Бизнес Букс, 2009. 936 с.

32.Бобров С.A. Природа та форми прояву валютного ризику // Вчені записки Університету «Крок»: Збірник наукових праць. 2009. №19. С. 69-76.

33. Кочии О.Е. Причины возникновения валютных рисков и их классификация // Организационно-экономические основы банковского менеджмента: сб. Ст.. / отв. ред. В.А. Гага. Томск : Изд-во Том. ун-та, 2006. Вып. 5. С. 82-84.

34.Ребрик M.A. Валютний ризик в умовах глобалізації ринку банківських послуг // Вісник Академії митної служби України. Серія Економіка. 2010. № 1 (43). С. 135-141.

35. Fundamental review of the trading book - consultative document, Basel Committee on Banking Supervision, May 2012, updated as of 19.12.2014 (Фундаментальный пересмотр подходов к оценке рыночного риска, Basel III) [Электронный ресурс]. URL: http://www.bis.org/bcbs/publ/ d305.htm (дата обращения 30.03.2015).

36.Волицька А.А. Валютні ризики як впливові чинники ведення банківського бізнесу // Проблеми і перспективи розвитку банківської системи України: збірник наукових праць / Державний вищий навчальний заклад «Українська академія банківської справи Національного банку України». Суми, 2005. Т. 13. С. 73-82.

37.Ребрик M.A. Управління структурними компонентами валютного ризику банку // Соціально-економічні проблеми сучасного періоду України. Фінансовий ринок України: стабілізація та євроінтеграція: зб. наук. праць / Інститут регіональних досліджень Національної академії наук України. Львів, 2009. Вип. 2 (76). С. 310-316.

38.Ребрик М.A. Види валютного ризику банку // Фінансово-кредитна діяльність: проблеми теорії та практики : зб. наук. праць / Харківський інститут банківської справи Університету банківської справи Національного банку України. Харків, 2010. Вип. 1 (8). Ч. 2. С. 56-62.

39.Jeffus W.M. Foreign exchange instruments, measuring and managing foreign exchange exposure [Electronic resource]. URL: http://www.wendyjeffus.com/research.html.

40.Лук'янова В.В., Головач Т.В. Економічний ризик: навч.посіб. К.: Академвидав, 2007. $464 \mathrm{c}$. 
K.T. Svieshnikova. Department of Management, Marketing and Law of Far East State Agrarian University, Blagoveshchensk, Amur region, Russia. E-mail: svieshnikova@mail.ru.

\section{COMPARATIVE ANALYSIS OF CURRENCY RISKS.}

Keywords: market risk, currency risk, commercial bank, bank, classification, Basel accords, Basel I, Basel II, Basel III.

The article investigates the nature of the category «currency risk», its place specifying in the classification of banking risks and the identification of influence's mechanisms to the commercial banks activities. Based on the analysis of different approaches the multicriteria classification's system of currency risks is proposed. Author offers these issues presented in the paper: the necessity of the stock, interest rate and currency risks combining in the market risks group, as well as fixing the common regulatory definition of currency risk in the legislation.

\section{References}

1. Otchety Banka mezhdunarodnyh raschetov za 1996 - $2013 \mathrm{gg}$. [The Reports of the Bank for International Settlements for 1996 - 2013]. Available at: http://www.bis.org/triennial.htm (accessed 30 March 2015). (In English).

2. Ghassem A.H. Managing Global Financial and Foreign Exchange Rate Risk [Text] / A.H. Ghassem. - Hoboken, New Jersey : John Wiley \& Sons, Inc., 2003. 400 p.

3. Murphy D. Understanding Risk. The Theory and Practice of Financial Risk Management / D. Murphy. - Taylor and Francis, 2008. - 472 p.

4. Papaioannou M.G. Exchange Rate Risk Measurement and Management: Issues and Approaches for Firms / M.G. Papaioannou // IMF Working Paper. 2006. Vol. 255. 22 p.

5. Redhead K., Hughes S. Financial Risk Management [Text] / Keith Redhead, H. Steward. Cambridge: Gower Pub Co, 1988. p. 257. ISBN 0-566-02652-X.

6. Shapiro Alan C. Multinational financial management [Text] / Alan C. Shapiro. - published by John Wiley and Son, Inc. -8 th edition. 2006. 768 p.

7. Butuk O.I. Valjutno-finansovi vidnosini. K.: Znannja, 2006. 349 p.

8. Vitlins'kij V.V. Rizikologija v ekonomici ta pidpriєmnictvi. K.: KNEU, 2004. 480 p. ISBN 966-574-569-7.

9. Gal'chins'kij A.S. Teorija groshej. K.: Vidavnictvo Solomiï Pavlichko «Osnovi», 2001. 412 p. ISBN 966-500-020-9.

10. Bankivs'kij menedzhment: pitannja teoriï ta praktiki. - Sumi: DVNZ «UABS NBU», 2011. 152 p. ISBN 978-966-8958-70-0.

11. Amendment to the Capital Accord to incorporate market risks / Basel Committee on Banking Supervision. - Basel, november 2005. Available at: http://www.bis.org/publ/bcbs119.pdf (accessed 30 March 2015).

12. Polozhenie o porjadke rascheta kreditnymi organizacijami razmera rynochnyh riskov (utv. Bankom Rossii 24.09.1999 №89-P) (red. ot 30.11.2004) (utratilo silu s 01.01.2008 v svjazi s izdaniem Ukazanija CB RF ot 14.11.2007 №1910-U).

13. Abstract of «Basel II: International Convergence of Capital Measurement and Capital Standards: a Revised Framework», Basel Committee on Banking Supervision,, June 2004. Available at: http://www.bis.org/publ/bcbs107.htm (accessed 30 March 2015).

14. Core Principles for Effective Banking Supervision, Basel Committee on Banking Supervision, October 2006, updated as of 14.09.2012). Available at: http://www.bis.org/publ/bcbs129.htm (accessed 30 March 2015).

15. O tipichnyh bankovskih riskah: Ukazanie Centrobanka Rossii №70-T ot 23.06.2004 // Vestnik Banka Rossii ot 30.06.2004. №38 (762). Available at: http://www.cbr.ru/Publ/Vestnik/ Ves040630038.zip (accessed 30 March 2015).

16. Polozhenie o porjadke rascheta kreditnymi organizacijami velichiny rynochnogo riska (utv. Bankom Rossii 14.11.2007 №313-P) (red. ot 28.04.2012) (Zaregistrirovano v Minjuste Rossii 06.12.2007 №10638) (utratilo silu s 01.02.2013 v svjazi s izdaniem Polozhenija Banka Rossii ot 28.09.2012 №387-P, utverdivshego novyj porjadok).

17. Revisions to Basel II market risk framework, Basel Committee on Banking Supervision, July 2009, updated as of 31.12.2010. Available at: http://www.bis.org/publ/bcbs193.htm (accessed 30 March 2015).

18. Polozhenie o porjadke rascheta kreditnymi organizacijami velichiny rynochnogo riska (utv. 
Bankom Rossii 28.09.2012 №387-P) (red. ot 25.11.2014) (Zaregistrirovano v Minjuste Rossii 09.11.2012 №25783).

19. Resolution of the NBU Board «Guidelines for the banks' inspection «The risk assessment system» of 15.03.2004 №104. Available at: http://zakon.rada.gov.ua/cgi-bin/laws/main.cgi? nreg=v0104500-04 (accessed 30 March 2015). (In Ukrainian).

20. Mishin O.Ju. Bagatokriterial'na sistema klasifikaciï rizikiv // Problemi i perspektivi rozvitku bankivs'koï sistemi Ukraïni: zbirnik naukovih prac' / Derzhavnij vishhij navchal'nij zaklad «Ukraïns'ka akademija bankivs'koï spravi Nacional'nogo banku Ukraïni». Sumi, 2005. T. 13. p. 98-103.

21.Jushhenko V.A., Mishhenko V.I. Upravlinnja valjutnimi rizikami. K.: Tovaristvo «Znannja», KOO, 1998. 444 p. ISBN 966-7293-29-7.

22. Grjuning Henni van. Analiz bankovskih riskov. Sistema ocenki korporativnogo upravlenija i upravlenija finansovym riskom. M.: Ves' mir, 2004. 304 p. ISBN 5-7777-0220-1.

23. Tkachuk N.M. Metodi upravlinnja valjutnim rizikom banku // Nauka j ekonomika. 2010. №2 (18). P. 106-112.

24. Sidolako M.S. Bankivs'ki riziki ta upravlinnja nimi // Problemi i perspektivi rozvitku bankivs'koï sistemi Ukraïni // Derzhavnij vishhij navchal'nij zaklad «Ukraïns'ka akademija bankivs'koï spravi Nacional'nogo banku Ukraïni». Sumi, 2007. T. 20. P. 261-265.

25. Risk Management Guidelines for Derivatives: Basel Committee on Banking Supervision, July 1994. Available at: http://www.bis.org/publ/bcbsc211.pdf (accessed 30 March 2015).

26. Rouz Piter S. Bankovskij menedzhment: per. s angl. s 3-go izd. M.: «Delo Ltd», 2008. 433 p.

27. Eiteman D.K. Multinational Business Finance / D.K. Eiteman, Arthur I. Stonehill, Michael H. Moffett. - Published by Addison-Wesley Longman, Inc. - 9th edition. - 2001. 784 p.

28. Resolution of the NBU Board «Guidelines on the organization and operation of risk management in banks of Ukraine» of 02.08.2004 №361. Available at: http://zakon.rada.gov.ua/cgibin/laws/main.cgi?nreg=v0361500-04 (accessed 30 March 2015). (In Ukrainian).

29. Order of the Ministry of Finance of Ukraine «Regulations (standard) accounting 13 «Financial Instruments» of 30.11.2001 №559 (as amended by 09.12.2011). Available at: http:// zakon.rada. gov.ua/cgi-bin/laws/main.cgi?nreg=z1050-01 (accessed 30 March 2015). (In Ukrainian).

30. Shelud'ko V.M. Finansovij rinok. K.: Znannja, 2006. 535 p. ISBN 978-966-346-375-9.

31.Lobanov A.A. Jenciklopedija finansovogo risk-menedzhmenta. M.: Al'pina Biznes Buks, 2009. $936 \mathrm{p}$.

32. Bobrov C.A. Priroda ta formi projavu valjutnogo riziku // Vcheni zapiski Universitetu «Krok»: Zbirnik naukovih prac'. 2009. №19. P. 69-76.

33. Kocin O.E. Prichiny vozniknovenija valjutnyh riskov i ih klassifikacija // Organizacionnojekonomicheskie osnovy bankovskogo menedzhmenta : cb.statej / otv. red. Gaga V. A. Tomsk : izd-vo Tom. un-ta, 2006. Vyp. 5. P. 82-84.

34. Rebrik M.A. Valjutnij rizik v umovah globalizaciï rinku bankivs'kih poslug // Visnik Akademiï mitnoï sluzhbi Ukraïni. Serija Ekonomika. 2010. № 1 (43). P. 135-141.

35. Fundamental review of the trading book - consultative document, Basel Committee on Banking Supervision, May 2012, updated as of 19.12.2014. Available at: http://www.bis.org/ bcbs/ publ/d305.htm (accessed 30 March 2015).

36. Volic'ka A.A. Valjutni riziki jak vplivovi chinniki vedennja bankivs'kogo biznesu // Problemi i perspektivi rozvitku bankivs'koï sistemi Ukraïni: zbirnik naukovih prac' / Derzhavnij vishhij navchal'nij zaklad «Ukraïns'ka akademija bankivs'koï spravi Nacional'nogo banku Ukraïni». Sumi, 2005. T. 13. P. 73-82.

37. Rebrik M.A. Upravlinnja strukturnimi komponentami valjutnogo riziku banku // Social'noekonomichni problemi suchasnogo periodu Ukraïni. Finansovij rinok Ukraïni: stabilizacija ta €vrointegracija: zb. nauk. prac' / Institut regional'nih doslidzhen' Nacional'noï akademiï nauk Ukraïni. L'viv, 2009. Vip. 2 (76). P. 310-316.

38. Rebrik M.A. Vidi valjutnogo riziku banku // Finansovo-kreditna dijal'nist': problemi teoriï ta praktiki : zb. nauk. prac' / Harkivs'kij institut bankivs'kö̈ spravi Universitetu bankivs'koï spravi Nacional'nogo banku Ukraïni. Harkiv, 2010. Vip. 1 (8). Ch. 2. P. 56-62.

39. Jeffus W.M. Foreign exchange instruments, measuring and managing foreign exchange exposure. Available at: http://www.wendyjeffus.com/research.html (accessed 30 March 2015).

40. Luk'janova V.V. Ekonomichnij rizik: navch.posib. K.: Akademvidav, 2007. 464 p. ISBN 9668226-37-2. 